\section{Newspaper response to the back pain myth busting advice: bruising but helpful}

Following on from recent newspaper articles, ${ }^{1}$ BJSM podcasts ${ }^{2}$ and the Chartered Society of Physiotherapy's recent Back Pain Myth buster campaign, ${ }^{3}$ a short article was published in the Daily Mail Online ${ }^{4}$ in August of this year. The article summarised the messages of the back pain myth buster campaign and advocated basic evidencebased approaches to exercise and management. The article was accessed over 29000 times with 125 reader comments being posted in the following 2 weeks.

Having reviewed the comments, it became apparent that there were a number of themes within the data and thus a colleague and I undertook a thematic analysis of the comments as described by Braun and Clarke. ${ }^{5}$ Using an interpretive approach to analyse the data, five themes emerged:

The readers' comments suggested that;

- Physiotherapists are not qualified to diagnose and manage back pain.

- Doctors are required to screen patients and arrange necessary MRI scans.

- Until screened by a doctor, exercise may be dangerous.

- There is a lack of empathy for back pain sufferers within the healthcare professions, borne of them not having suffered it as badly themselves.

- A feeling that the advice to exercise is trivialising their problem and that there is a suggestion that the pain is all in their minds.

While it was heartening to see some agreement with the suggestion that exercise for back pain can be helpful, this was not a strong theme and the general emotional response to the article was of annoyance, in contrast to the professional social media response to the myth buster campaign which was overwhelmingly enthusiastic. ${ }^{6}$ While reviewing the comments was a personally bruising experience, it has been valuable in reminding us of the challenges ahead. The anonymity of the comments in this forum certainly allowed for some personally insulting comments to be posted; however, the themes that emerged may reflect an unfettered reflection of a discord between back pain sufferers' expectations of the healthcare system and the healthcare they receive.

The comments from Daily Mail Online readers highlighted to us the need to reflect on the perceptions of sufferers of back pain and to use stakeholder perceptions to adapt our methods of communication. We accept that journalistic editorial, illustration and headlining can sometimes counteract the carefully chosen language, within the body of an article. However, direct communication with stakeholders, via mass media, plays an important role in improving public health.

Clearly, we still have a way to go in matching the expectations of some back pain sufferers with our recommendations on appropriate investigations, professional scope of practice and the interventions they receive. Modern, interactive, national newspapers can strongly influence their readership, and now it seems influence their writers!

\section{Christopher J McCarthy, Gillian Yeowell}

School of Physiotherapy, Manchester Metropolitan University, Manchester, UK

Correspondence to Dr Christopher J McCarthy, School of Physiotherapy, Manchester Metropolitan University, Manchester M15 6BH, UK; cmccarthy@ mmu.ac.uk

Twitter Follow Christopher McCarthy @combinedmover

Contributors CJM was the author of the letter. GY devised and undertook qualitative analysis of the data set.
Competing interests None declared.

Provenance and peer review Not commissioned; externally peer reviewed.

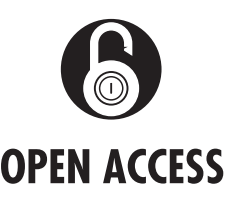

Open Access This is an Open Access article distributed in accordance with the Creative Commons Attribution Non Commercial (CC BY-NC 4.0) license, which permits others to distribute, remix, adapt, build upon this work non-commercially, and license their derivative works on different terms, provided the original work is properly cited and the use is noncommercial. See: http://creativecommons.org/licenses/ by-nc/4.0/

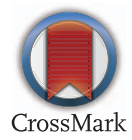

To cite McCarthy CJ, Yeowell G. Br I Sports Med 2017;51:758.

Accepted 13 November 2016

Published Online First 17 January 2017

Br J Sports Med 2017;51:758.

doi:10.1136/bjsports-2016-097253

\section{REFERENCES}

1 Dr Mary O'Keefe's article in the Independent.ie. http:// www.independent.ie/life/health-wellbeing/ how-to-move-on-from-back-pain-34998028.html

2 Dr Keiron O'Sullivan's BJSM podcast on back pain. https://soundcloud.com/bmjpodcasts/dr-kieranosullivan-on-managing-back-pain-7-habits-of-highlyeffective-clinicians-part-2-2016

3 CSP Mythbuster campaign. http://www.csp.org.uk/ your-health/healthy-living/public-information-leaflets/ back-pain-myth-busters

4 Daily Mail back pain article. http://www.dailymail.co. uk/health/article-3753221/Revealed-5-myths-lowerpain-Pain-doesn-t-equal-damage-s-no-need-avoidexercise-heavy-school-bag-isn-t-blame.html

5 Braun V, Clarke V. Successful qualitative research. London: Sage, 2013.

6 Twitter reaction to myth busters. https://twitter.com/ search?q=\%23backmyths\&src=typd 